\title{
IMPLEMENTING LAPAROSCOPY IN BRAZIL'S NATIONAL PUBLIC HEALTH SYSTEM: THE BARIATRIC SURGEONS' POINT OF VIEW
}

\author{
Adesão dos cirurgiões bariátricos à laparoscopia no sistema único de saúde do brasil
}

Samanta SUSSENBACH ${ }^{1,2}$, Everton N SILVA ${ }^{3}$, Milene Amarante PUFAL ${ }^{1,2}$, Carina ROSSONI ${ }^{2,4}$, Daniela Schaan CASAGRANDE ${ }^{1}$, Alexandre Vontobel PADOIN ${ }^{1,2}$, Cláudio Corá MOTTIN ${ }^{1,2}$

From the ${ }^{1}$ Centro da Obesidade e Síndrome Metabólica do Hospital São Lucas, Pontifícia Universidade Católica do Rio Grande do Sul, Porto Alegre, RS; ${ }^{2}$ Pós-Graduação em Medicina e Ciências da Saúde da Pontifícia Universidade Católica do Rio Grande do Sul Porto Alegre, RS; ${ }^{3}$ Faculdade de Ceilândia da Universidade de Brasília, Brasília, $\mathrm{DF} ;{ }^{4}$ Centro Integrado de Tratamento à Obesidade, Chapecó, SC, Brazil.

HEADINGS - Bariatric surgery. Gastric bypass. Laparoscopy.
ABSTRACT - Background: Although Brazilian National Public Health System (BNPHS) has presented advances regarding the treatment for obesity in the last years, there is a repressed demand for bariatric surgeries in the country. Despite favorable evidences to laparoscopy, the BNPHS only performs this procedure via laparotomy. Aim: 1) Estimate whether bariatric surgeons would support the idea of incorporating laparoscopic surgery in the BNPHS; 2 ) If there would be an increase in the total number of surgeries performed; 3 ) As well as how BNPHS would redistribute both procedures. Methods: A panel of bariatric surgeons was built. Two rounds to answer the structured Delphi questionnaire were performed. Results: From the 45 bariatric surgeons recruited, 30 (66.7\%) participated in the first round. For the second (the last) round, from the 30 surgeons who answered the first round, $22(48.9 \%)$ answered the questionnaire. Considering the possibility that BNPHS incorporated laparoscopic surgery, $95 \%$ of surgeons were interested in performing it. Therefore, in case laparoscopic surgery was incorporated by the BNPHS there would be an average increase of $25 \%$ in the number of surgeries and they would be distributed as follows: $62.5 \%$ via laparoscopy and $37.5 \%$ via laparotomy. Conclusion: 1) There was a preference by laparoscopy; 2) would increase the number of operations compared to the current model in which only the laparotomy is available to users of the public system; and 3) the distribution in relation to the type of procedure would be $62.5 \%$ and $37.5 \%$ for laparoscopy laparotomy.

\section{Correspondence:}

Cláudio Corá Mottin

e-mail:samysuss@gmail.com

Financial source: FINEP (Brasil)

Conflicts of interest: none

Received for publication: 04/02/2014

Accepted for publication: 08/05/2014

DESCRITORES - Cirurgia bariátrica Derivação gástrica. Laparoscopia.
RESUMO - Racional: Nos últimos anos, apesar do Sistema Único de Saúde Brasileiro - SUS - apresentar avanços relacionados à organização e ampliação das ações voltadas à prevenção e ao tratamento da obesidade, existe demanda reprimida de operações no país. Mesmo com evidências favoráveis à operação por via laparoscópica, o SUS só permite o procedimento por via laparotômica. Objetivos: 1) Estimar se os cirurgiões bariátricos apoiariam eventual incorporação da operação por via laparoscópica no SUS; 2) se haveria incremento no número total de operações caso houvesse esta nova opção de via de acesso; e 3) como seria a redistribuição da oferta de operações pelas duas vias. Métodos: Com o método Delphi, foi construído um painel de especialistas, em que cirurgiões bariátricos responderam um questionário estruturado previamente desenvolvido para esse fim. Foram realizadas duas rodadas, no intuito de melhor consenso. Resultados: Dos 45 cirurgiões que estiveram presentes no evento nacional, 30 (66,7\%) participaram do questionário Delphi, o que correspondeu à primeira rodada do estudo. Na segunda, e última rodada, dos 30 respondentes da primeira etapa, $22(48,9 \%)$ cirurgiões responderam. Mediante a possibilidade de incorporação da via laparoscópica no SUS, aproximadamente $95 \%$ dos cirurgiões manifestaram interesse em realizá-la. Caso a operação por laparoscopia fosse incorporada no SUS, haveria incremento médio no número de operações na ordem de $25 \%$; nesta nova configuração, a oferta de procedimentos cirúrgicos estaria distribuída da seguinte forma: $62,5 \%$ por laparoscopia e 37,5\% por laparotomia. Conclusão: 1) Houve preferência pela via laparoscópica; 2) haveria incremento no número de operações comparado ao modelo atual em que apenas a via laparotômica está disponível aos usuários do sistema público; e 3) a distribuição em relação ao tipo de procedimento seria de $62,5 \%$ por laparoscopia e 37,5\% por laparotomia.

INTRODUCTION

$\mathrm{D}$ espite advances in health field, obesity has been an increasing problem for public health in the last decades ${ }^{1,2}$, both in developed and in developing countries, showing high rates of morbidity and mortality ${ }^{3,4}$.

According to the World Health Organization (WHO) ${ }^{5}$, the prevalence of overweight in the world is about 1.9 billion people and about 600 million are obese. According to the Brazilian Survey of Surveillance of Risk Factors and Protection for Chronic Diseases by Telephone Inquiry (Vigitel) ${ }^{6}$, for the first time the percentage of people with overweight overcomes more than half of Brazilian population, i.e., $51 \%$ of population older than 18 years old is above the ideal weight, $52 \%$ men and $48 \%$ women. At the age between 18 and $24,24 \%$ of population is above the ideal weight and $7 \%$ is obese. For people aged 35 and 44 , these numbers are $55 \%$ and $19 \%$ respectively. If nothing is done to reverse this epidemic, there is an estimative that by 2030 there will be three billion obese people worldwide ${ }^{7}$.

The Brazilian National Public Health System (BNPHS) was created in 1988. It grants all citizens the right to get medical assistance, exams, hospitalization, and treatment in 
accredited health centers. About $75 \%$ of Brazilian population depends solely on this system ${ }^{8}$. Currently the BNPHS counts on 78 accredited health facilities to provide high standard assistance to patients with morbid obesity ${ }^{9}$ throughout 20 states. Twelve of these states have not achieved 96 procedures a year, as requested by the present legislation to keep the accreditation, which indicates inequality of access for morbid obese to the surgical procedure in those states. At national level, 5,357 surgeries were performed in 2011 in the BNPHS and, in 2012, this number increased slightly (almost 6,000 surgeries). However, in the private sector (private health insurance and direct payment), about $64,000^{10}$ surgeries were performed in 2012, i.e., almost 11 times the amount of surgeries performed by BNPHS. In the last years, although BNPHS has presented improvements concerning organization and expansion of preventive actions and treatment for obesity, the supply for this surgery coverage in the country is still very low ${ }^{10}$.

Another important issue to be considered is that laparoscopic surgery is not available in the BNPHS, even scientific evidences pointing to the fact that laparoscopic access is superior when compared to laparotomy in terms of reduction mortality ${ }^{11}$ and morbity ${ }^{11,12}$, faster recovery ${ }^{13}$, better healing ${ }^{14}$, reduction of immediate and late complications such as operatory wound ${ }^{13,14}$, incisional hernias, fistulas and adherence $^{15}$.

The objective of this study was to estimate: 1) whether bariatric surgeons would support an eventual incorporation of laparoscopy by the BNPHS; 2) whether there would be an increase in the total amount of surgeries performed by the BNPHS in case there was this new via of access; and 3) what would be the distribution between laparoscopy and laparotomy accesses if both were available in the BNPHS.

\section{METHODS}

For this application of the Delphi method, was constructed a panel of experts. From 45 bariatric surgeons who attended the national event of the Brazilian Society of Metabolic and Bariatric Surgery held in June 2013, 32 participated in the survey, responding to a structured questionnaire previously developed for this purpose. In October 2013, which corresponded to the second round, the same questionnaire was applied, however, by electronic means (e-mail) to all participants in the first round.

In two rounds, besides a brief introduction about the objective of the questionnaire, three questions were asked:

Currently, how many Roux-en-Y gastric bypass (BPGYR) via laparotomy (open) are monthly performed in the hospital where you work sponsored by NPHS?

In case laparoscopic access (video) was incorporated by NPHS, would the medical team be interested in perform it?

In the new scenario where NPHS would sponsor both access - open and video - how much would you expect NPHS needs to offer for BPGYR in your hospital?

These questions were asked aiming to know about three issues: 1) surgeon interest for an eventual incorporation of laparoscopic access by the BNPHS; 2) the potential increase in the offer of surgeries by the BNPHS in case laparoscopic access was incorporated; and 3) what would surgeons choose if surgeries by both via, laparotomy and laparoscopy, were available.

\section{Statistical analyses}

Data analyses were conducted by the program SPSS 19.0. Quantitative variables with asymmetric distribution were described by median and interquartile interval and then compared by Wilcoxon's test. For categorical variable it was used the test of Mac Nemar. It was considered as level of significance $5 \%$.
RESULTS

From the 45 bariatric surgeons who attended the Brazilian Society of Metabolic and Bariatric Surgery event in 2013, 32 answered the Delphi questionnaire (Table 1), which represented the first round of the study. However, two specialists were not able to answer it, as they did not perform surgeries via laparotomy. Thus, 30 surgeons effectively participated in the first round. In the second, and last round, from the 30 respondents, 22 answered the questionnaire.

TABLE 1 - Panel of specialists who answered the Delphi questionnaire

\begin{tabular}{|c|c|c|c|}
\hline Region & $\begin{array}{l}\text { Participants who } \\
\text { answered the } \\
\text { questionnaire, } \mathrm{n}(\%)\end{array}$ & $\begin{array}{l}\text { Participants in } \\
\text { the first round, } \\
\mathrm{n}(\%)\end{array}$ & $\begin{array}{l}\text { Participants in the } \\
\text { second round, } \\
\text { n (\%) }\end{array}$ \\
\hline South & $8(25)$ & $8(26.7)$ & $7(31.8)$ \\
\hline Southeast & 18 (56.3) & 17 (56.6) & 12 (54.6) \\
\hline Northeast & $5(15.6)$ & $5(16.7)$ & $3(13.6)$ \\
\hline $\begin{array}{c}\text { Center- } \\
\text { West }\end{array}$ & 1 (3.1) & - & - \\
\hline Total & $32(100)$ & $30(100)$ & $22(100)$ \\
\hline
\end{tabular}

Table 2 shows the results of both rounds of questionnaires answered by the specialists. As observed in question 1 , there was no statistically significant change in the number of surgeries performed via laparotomy by the BNPHS between both rounds. Regarding question 2, two specialists changed their opinion from one round to the other. When comparing answers from the two rounds it was observed that there was an interest over to 95\% for the laparoscopic access and no statistically significant change between rounds.

TABLE 2 - Questions 1, 2 and 3 of Delphi questionnaire in both rounds

\begin{tabular}{|c|c|c|c|}
\hline $\begin{array}{c}\text { Questions }(\mathrm{Q}) \text { from Delphi } \\
\text { questionnaire }\end{array}$ & $\begin{array}{l}\text { First } \\
\text { round }\end{array}$ & $\begin{array}{l}\text { Second } \\
\text { round }\end{array}$ & $\mathrm{Q}$ \\
\hline $\begin{array}{l}\text { Q1 - Number of surgeries } \\
\text { performed by laparotomy by the } \\
\text { BNPHS (median, P25-75) }\end{array}$ & $\begin{array}{c}N(29) 1 \\
10^{*}\left(3-14^{\star}\right)\end{array}$ & $\begin{array}{c}N(22) 3 \\
10^{\star}\left(3.5-16^{\star}\right)\end{array}$ & 0.88 \\
\hline $\begin{array}{l}\text { Q2 - Is there interest in } \\
\text { incorporating laparoscopy into } \\
\text { the BNPHS? (Yes, n-\%) }\end{array}$ & $\begin{array}{c}N(29) 1 \\
28^{*}\left(96.6^{\star *}\right)\end{array}$ & $\begin{array}{c}N(22) 3 \\
21^{\star}\left(95.5^{\star *}\right)\end{array}$ & . \\
\hline $\begin{array}{l}\text { Q3 - In case laparoscopy } \\
\text { was incorporated into the } \\
\text { BNPHS how would be the } \\
\text { redistribution? (median, P25-75) } \\
\text { OGB*** } \\
\text { LGB**** }\end{array}$ & $\begin{array}{l}N(27) 2 \\
0(0-5.75) \\
9(5-12)\end{array}$ & $\begin{array}{l}N(22) 3 \\
1(0-9) \\
9(5-18)\end{array}$ & $\begin{array}{l}0.48 \\
0.30\end{array}$ \\
\hline
\end{tabular}

Notes: ${ }^{*}$ numerical values; ${ }^{* *}$ percentages; ${ }^{* * *} \mathrm{OGB}=$ open gastric bypass or laparotomy; ${ }^{* * \star} \mathrm{LGB}=$ laparoscopic gastric bypass; $1-29 / 30$, because one participant did not answer this question; $2-27 / 30$, because three participants did not answer this question; $3-22 / 30$, because eight participants did not answer.

In case video laparoscopic surgery was incorporated into the BNPHS, there would be an average increase of $25 \%$ in the number of surgeries; in this new configuration, surgeries would be offered as follows: $62.5 \%$ laparoscopy and $37.5 \%$ laparotomy.

\section{DISCUSSION}

This paper showed the opinion of bariatric surgeons about an eventual incorporation of laparoscopic surgery into the Brazilian public health system. It seems that there is a strong support by these professionals in favor to laparoscopic surgeries in terms of introducing them in the public health 
system. Besides, it was observed that it would let an increase in the number of surgeries when compared to the current model in which only laparotomy is available for users of public health system. The surgeons' preference for laparoscopic access would correspond to more than $60 \%$ of surgical interventions.

Studies have shown that bariatric surgery performed by laparoscopic access has the best cost-benefit ratio. According to Guzmán et $a{ }^{18}$, by this procedure access, there are lower rates of complications in the operatory wound, better pulmonary function, shorter time in hospital, minor probability of re-intervention, low rate of mortality, lower probability of either immediate or later complications such as incisional hernia, fistulas, adherences ${ }^{4}$. Furthermore, patients report less pain after surgery ${ }^{5,19}$ there is a smaller loss of blood during surgery procedure ${ }^{4,20,21}$ and better healing ${ }^{21,22}$. When compared, laparotomy and laparoscopy presented a rate of hernia of, respectively, $9.1 \%$ and $0.8 \%{ }^{20}$. Shabanzadeh and Sorensen ${ }^{22}$ observed that infection risk in operatory wound was $70-80 \%$ lower when the surgery was performed by laparoscopy.

The number of bariatric surgeries has increased a lot in the last decade. According to Buchwald and Oien ${ }^{23}$, USA/Canada and Brazil are populous countries that have lead the activity of bariatric surgery in the last eight years with 101,645 and 65,000 cases respectively. Brazil showed an increase of $260 \%$ from 2008 to 2011 (25,000 to 65,000 cases) and the number of bariatric surgeons increased in 393\% (from 700 to 2,750).

Currently, public health service has offered the possibility to perform bariatric surgery in accredited centers, and the procedure is part of an extensive program that consist of pre-operatory assessment and post operatory follow up, which includes reconstructive plastic surgery ${ }^{27}$. According to the Brazilian Health Ministry ${ }^{9}$, the goal for each accredited center by NPHS is 96 procedures a year; however, it has not been achieved by most of centers. In case this surgery was implemented by the laparoscopic access there would be the possibility to achieve the goal easier as this technique spends less time to be performed. Thus, there would be coverage of at least 7,488 surgeries a year, an increase of $25 \%$ in the number of current surgeries, which reinforces the results of this study.

The results in this study show that each center performs a different amount of laparotomic procedures by the BNPHS, which varies from two to 65 surgeries per month. So, if laparoscopic surgery was incorporated into the system, there would be an average increase of $25 \%$, and these surgeries would show a different distribution: $62.5 \%$ by laparoscopy and $37.5 \%$ by laparotomy.

There is an unmet demand for bariatric surgeries in the country; obesity and associated comorbidities are responsible for $72 \%$ of all causes of death in Brazil24. The BNPHS spends $\mathrm{R} \$ 488$ million a year on treatment of diseases associated to obesity (hypertension, cancer and cardiovascular diseases among others); waiting lines to undergo this surgical procedure last on average six to 12 years, and up to $10 \%$ of patients die meanwhile ${ }^{24}$.

According to specialists, the low number of procedures performed is one of the greatest negative aspects of the service offered by the public health service. This difficulty is a result of several reasons (inadequate structure, lack of necessary material, lack of procedures' standardization), and the virtual disincentive of professionals working in bariatric serviced due to medical fees and hospital services ${ }^{24}$. This lack of updating of the number of procedures discourages an increase of these interventions in public hospitals. The proof of this is that bariatric surgeries by NPHS represent only $10 \%$ of the total bariatric surgeries performed in the country. While in the private sector there are more than 60,000 surgeries a year, NPHS performs about 6,000 interventions and all via laparotomy ${ }^{24}$.

In this study, taken into consideration the possibility of incorporating laparoscopic surgery in the BPHS, about $95 \%$ of surgeons showed interest in performing it. Those who suggested that some surgeries could be performed by laparotomy said that medical residents need to have the ability and knowledge to perform surgery via both accesses.

Although bariatric surgery costs performed via laparoscopy are higher ${ }^{25}$ when compared to laparotomy ${ }^{12,26,27}$, evidences are favorable concerning safety and tolerance by patients ${ }^{11,26,27}$. Moreover it shows to be effective to solve comorbidities and loss of weight when compared to the conservative obesity treatment ${ }^{28}$. Additional costs due to laparoscopic access are eventually compensated by lower probability of complications after surgery ${ }^{13-16,29}$ and, consequently, by the costs to solve them.

\section{CONCLUSION}

1) There was a preference by laparoscopy; 2) would increase the number of operations compared to the current model in which only the laparotomy is available to users of the public system; and 3) the distribution in relation to the type of procedure would be $62.5 \%$ and $37.5 \%$ for laparoscopy and laparotomy.

\section{REFERENCES}

1. Batsis JA, Clark MM, Grothe $K$ et al. Self-efficacy after bariatric surgery for obesity.A population-based cohort study. Appetite.2009; 52:637-45.

2. Keating $C L$, Dixon JB, Moodie ML et al. Cost-efficacy of surgically induced weight loss for the management of Type 2 Diabetes. Diabetes Care 2009; 32:580-584.

3. Elder KA, Wolfe BM. Bariatric Surgery: a review of Procedures and Outcomes. Gastroenterology 2007;132:2253-71.

4. Sharma A M. Managing weight issues on lean evidence: the challenges ofbariatric medicine. Canadian Medical Association Journal. 2005;172 n 1 p. 30-1.

5. World Health Organization. Obesity and overweight fact sheet $\mathrm{N}^{\circ}$ 311, March 2013. Acessado de http://www.who.int/mediacentre/ factsheets/fs311/en/ em 23 de novembro de 2013.

6. Vigitel Brasil 2012 - Vigilância de Fatores de Risco e Proteção para Doenças Crônicas por Inquérito Telefônico. Acessado de http://portalsaude.saude.gov.br/portalsaude/arquivos/pdf/2013/ Nov/26/Relatorios_Vigitel_2012.pdfem 02 de dezembro de 2013.

7. Kelly T, Yang W, Chen CS, et al. Global burden of obesity in 2005 and projections to 2030. Int J Obes (Lond). 2008; 32:1431-7. Lancet.2011; 377:557-67.

8. Brasil. Ministério da Saúde. Secretaria-Executiva. Área de Economia da Saúde e Desenvolvimento. Avaliação econômica em saúde: desafios para gestão no Sistema Único de Saúde / Ministério da Saúde, Secretaria -Executiva, Área de Economia da Saúde e Desenvolvimento. - Brasília: Editora do Ministério da Saúde, 2008. 104 p.: il. - (Série A. Normas e Manuais Técnicos) http://portal. saude.gov.br/portal/arquivos/pdf/livro_aval_econom_saude.pdf Pesquisa realizada em 26 de setembro de 2011.

9. Relatório de Gestão 2011. Acessado de http://portal.saude.gov.br/ portal/arquivos/pdf/SAS_Relatorio_de_Gestao_2011.pdf em 21 de novembro de 2013.

10. Oliveira ML. Estimativa dos custos da obesidade para o Sistema Único de Saúde do Brasil. Brasília, 2013.

11. Tiwari MM, Reynoso JF, High R et al. Safety, efficacy, and costeffectiveness of commomlaparosocopic procedures. Surg Endosc. 2011;25:1127-1135.

12. Salem L, Devlin A, Sullivan SD et al. A cost-effectiveness analysis of laparoscopic gastric bypass, adjustable gastric banding and nonsurgical weight loss interventions. SurgObesRelat Dis. 2008; 4:26-32.

13. Reosch J, Mottillo S, ShimonyA et al. Safety of laparoscopic vs open bariatric surgery. A systematic review and meta-analysis. Arch Surg. 2011;146:1314-1322

14. Barbash GI, Glied SA. New technology and health care costs - the case of robot-assisted surgery. N Engl J Med. 2010;363:701-704.

15. Brethauer SA, Chand B, Schauer PR. Risks and benefits of bariatric surgery: Current evidence. Cleveland Clinic Journal of Medicine. 2006;73:993-1007. 
16. Buchwald H et al. Bariatric Surgery A Systematic Review and Metaanalysis. JAMA.2004;292: 1725-37.

17. Ministério da Saúde - Secretaria de Ciência, Tecnologia e Insumos Estratégicos Departamento de Ciência e Tecnologia. Diretrizes Metodológicas - Elaboração de Estudos para Avaliação de Equipamentos médico-assistenciais. 2013. Disponível http://www. saude.gov.br/bvs

18. Guzmán S, Manrique M, Raddatz A, Norero E, Salinas J et al Experiencia de 18 años de cirugía de obesidad en la Pontificia Universidad Católica de Chile - Results of bariatric surgery. Rev. méd. Chile. 2013;141 no 5.

19. Padwal RS, Sharma AM. Treating Severe Obesity: Morbid Weights and Morbid Waits. CMAJ. 2009:181(11)

20. Garrido Jr AB et al. Cirurgia da obesidade. São Paulo, Ed Atheneu, 2006.

21.Lima LP, Sampaio HAC. Caracterização socioeconômica, antropométrica e alimentar de obesos graves. Ciênc. Saúde coletiva. 2007;12(4)Rio de Janeiro jul./ago.

22. Shabanzadeh DM, Sorensen LT. Laparoscopic Surgery compared with Open Surgery decreases surgical site infection in obese patients: a Systematic Review and meta-analysis. Ann Surg. 2012;
256(6):934-45.

23. Buchwald H, Oien DM. Metabolic/Bariatric Surgery Worldwide 2011.Obes Surg. 2013;23: 427-36.

24. SBCBM - Sociedade Brasileira de Cirurgia Bariátrica e Metabólica. Acessado de http://www.sbcb.org.br/ em 08 de dezembro de 2013.

25. Gould JC, Garren MJ, Starling JR. Laparoscopic gastric bypass results in decreased prescription medication costs within 6 months. Journal of Gastrointestinal Surgery. 2004;8:983-987.

26. Jones KB, Afram JD, Benotti PN et al. Open versus laparoscopic Roux-en-Y gastric bypass: a comparative study of over 25,000 open cases and the major laparoscopic bariatric reported series. Obes Surg. 2006;16:721-727.

27. Weller WE, Rosati C. Comparing outcomes of laparoscopic versus open bariatric surgery. Ann Surg. 2008; 248:10-15.

28. Encinosa WE, Bernard DM, Steiner CA et al. Use and costs of bariatric surgery and prescription weight-loss medications. Treatment for obesity has skyrocketed since 1998 , but coverage policies remain uneven across insurers. Health Affairs. 2005; 24:1039-1046.

29. El-Kadre L, Tinoco AC, Tinoco RC et al. Overcoming the learning curve of laparoscopic Roux-en-Y gastric bypass: A 12-year experience. Surg Obes Relat Dis. 2013; e. 